\title{
Assessing Water Availability and Unmet Water Demand Using the WEAP Model in the Semi-Arid Bweengwa, Kasaka and Magoye Sub-Catchments of Southern Zambia
}

\author{
Tewodros M. Tena ${ }^{1 *}$, Alick Nguvulu², Dickson Mwelwa ${ }^{3}$, Phenny Mwaanga ${ }^{2}$ \\ ${ }^{1}$ Department of Environmental Engineering, Copperbelt University, Kitwe, Zambia \\ ${ }^{2}$ Department of Geomatics Engineering, Copperbelt University, Kitwe, Zambia \\ ${ }^{3}$ Business and Information Technology Department, Cavendish University, Lusaka, Zambia \\ Email: ^tewodroslina@yahoo.com, alick.nguvulu@cbu.ac.zm,dickson.mwelwa@yahoo.com
}

How to cite this paper: Tena, T.M., Nguvulu, A., Mwelwa, D. and Mwaanga, P. (2021) Assessing Water Availability and Unmet Water Demand Using the WEAP Model in the Semi-Arid Bweengwa, Kasaka and Magoye Sub-Catchments of Southern Zambia. Journal of Environmental Protection, 12, 280-295.

https://doi.org/10.4236/jep.2021.124018

Received: March 11, 2021

Accepted: April 26, 2021

Published: April 29, 2021

Copyright $\odot 2021$ by author(s) and Scientific Research Publishing Inc. This work is licensed under the Creative Commons Attribution International License (CC BY 4.0).

http://creativecommons.org/licenses/by/4.0/ (c) (i) Open Access

\begin{abstract}
Located in the semi-arid zone of Zambia, the Mutama-Bweengwa, Kasaka and Magoye sub-catchments have witnessed a high demand for water due to increase in population and socio-economic activities putting more pressure on water resources. This study assesses the hydrological components and ascertains the available water resources and unmet demand in the sub-catchments using the Water Evaluation And Planning (WEAP) Model and hydrometeorological data collected between 1951 and 2018. The model was calibrated and validated on 1971-1981 and 2008-2018 data respectively. The results reveal that the sub-catchments have transitioned from positive to negative water balance with -164.295 $\mathrm{Mm}^{3} /$ year for Mutama-Bweengwa, $-19.021 \mathrm{Mm}^{3} /$ year for Kasaka and $-86.368 \mathrm{Mm}^{3} /$ year for Magoye. Evaporation was $1815.259 \mathrm{Mm}^{3} /$ year for Mutama-Bweengwa, $1162.655 \mathrm{Mm}^{3} /$ year for Kasaka and $1505.664 \mathrm{Mm}^{3} /$ year for Magoye. The demand for water has been increasing over time for various purposes such as irrigation, domestic, urban/rural water supply and livestock. The overall water storage in the sub-catchments showed a negative water balance for the year 2018. The observed and simulated peak streamflow were $8.16 \mathrm{~m}^{3} / \mathrm{s}$ and $7.7 \mathrm{~m}^{3} / \mathrm{s}$ occurring during the month of January and February respectively. The WEAP model performance achieved $\mathrm{R}^{2}$ of 0.98 during calibration and 0.95 for validation, and an NSE of 0.83 for calibration and 0.85 during validation. The values of objective functions show that the hydrology of the Mutama-Bweengwa, Kasaka and Magoye sub-catchments as predicted by the WEAP model provides satisfactory confidence for prediction of future streamflow and hence projection based on future scenarios.
\end{abstract}




\section{Keywords}

Water Availability, Water Use, WEAP Model, River Catchment, Streamflow, Semi-Arid Catchment Hydrology

\section{Introduction}

\subsection{Background}

Water is an important resource that drives economies and social well-being of human societies. Understanding the processes that control the existence of water resource, its variability in time and space, and the ability to quantify its availability is important for its sustainable management and efficient allocation among competing users [1]. Water availability and scarcity are a concern not only for future but they are now a reality in the developed world [2] as well as the developing world [3]. Non-availability of water has the potential to retard desirable economic and social development in a given society. Conflicts over future water allocations for various purposes have been reported both in advanced countries [2] and the developing countries. Therefore analysis and quantification of water availability, water use and water management are key issues. Water availability is simply the supply of water in excess of that currently allocated for consumptive use in a particular basin; that is, the amount of water available for new development. It is one of the most important indicators of sustainable development in modern society. According to Tidwell [4], population growth coupled with industrial and agricultural expansion brings about new demands for water, further putting more stress on water availability. As observed by Barlow [5], water availability and use greatly depends on the basin hydrology, climate, use characteristics, legal and regulatory institutions, and personal values of the basin inhabitants. Characterizing water availability requires data on both water availability and the dynamics of water resources use in a region.

The question that arises then is "where in the catchment and how might the development of new agricultural, settlement and industrial projects be challenged by limited water availability?" Answering this question requires data characte-

rizing the current water use in a catchment and the hydrological processes such as precipitation, interception, evapotranspiration, infiltration, surface runoff, groundwater recharge, sediment yield, streamflow and catchment storage. Streamflow strongly influences the hydrology of a basin. For instance, streamflow reduction affects water supply for human consumption as well as maintenance of in streamflow requirements for other environmental needs [5]. Streamflow is one of the most important components in hydrological processes and exhibits spatial and temporal variability. It plays an important role in water resources assessment and management. Understanding the characteristics of the streamflow is vital in the hydrological modelling of a catchment [6]. Long-term analysis of streamflow 
is of critical importance for water resources assessment and the sustainable and equitable utilization among the various uses in a catchment. This is where hydrological and water allocation models, like the WEAP Model, become useful tools for water resources management studies. These models are capable of accurately evaluating, modelling and predicting the dynamics of water balance of a watershed using meteorological data and watershed conditions.

The Southern Region of Zambia has recently been hit with limited water availability or total lack of it in some cases. The specific catchments affected by limited water availability with strategic significance to the socio-economic development of the semi-arid Southern Region of Zambia are the Mutama-Bweengwa, Kasaka and Magoye sub-catchments. The sub-catchments are predominantly rural in nature, but the increasing population and rapid agricultural and urbanization developmental projects taking place there have introduced several environmental sustainability issues including increased water demand by various users. Coupled with low rainfall received in the region $650-800 \mathrm{~mm}$ [7], the increase in water demand has led to water scarcity and unsustainable exploitation of groundwater for livelihoods.

This study applies the Water Evaluation and Planning (WEAP) Model to assess the available water resources and simulate the unmet water demand under different future scenarios in the Mutama-Bweengwa, Kasaka and Magoyesubcatchments by analyzing historical hydrometeorological data from 1951 to 2018 . The WEAP Model [8] [9] is an integrated water resource planning tool. Several studies have applied the WEAP Model to represent current water conditions at catchment level [10] [11], to explore a wide range of demand and supply options for balancing environment and development [12], to determine relations between reservoir storage, in streamflow, and water supply yield [13], to investigate and assess scenarios of future water resource development under different demands [14] [15] [16] and under irrigation and climate change scenarios [17], and to model the response of small multi-purpose reservoirs to hydrology for improved rural livelihoods [18]. It is for this reason that the WEAP model was adopted and applied in this study. The study then recommends sustainable catchment protection and river restoration strategies based on the findings.

\subsection{Study Area}

The Mutama-Bweengwa, Kasaka and Magoye water users are located across Mazabuka, Monze, Pemba, Choma, Chikankata and Kolomo administrative Districts in the Southern Province of Zambia and hydrologically located in Lower Kafue Sub-Catchment as shown in Figure 1. Mutama-Bweengwa, Kasaka and Magoye sub-catchments comprise of three hydrological river systems namely Bweengwa (Mutama-Bweengwa), Kasaka and the Magoye River systems which contribute significantly to the Kafue Flats. The hydrological sub-catchment area for Mutama-Bweengwa, Kasaka and Magoye is approximately $2305.8 \mathrm{~km}^{2}$, $1497.8 \mathrm{~km}^{2}$ and $2038.2 \mathrm{~km}^{2}$ and the length of the rivers from headwaters to their 


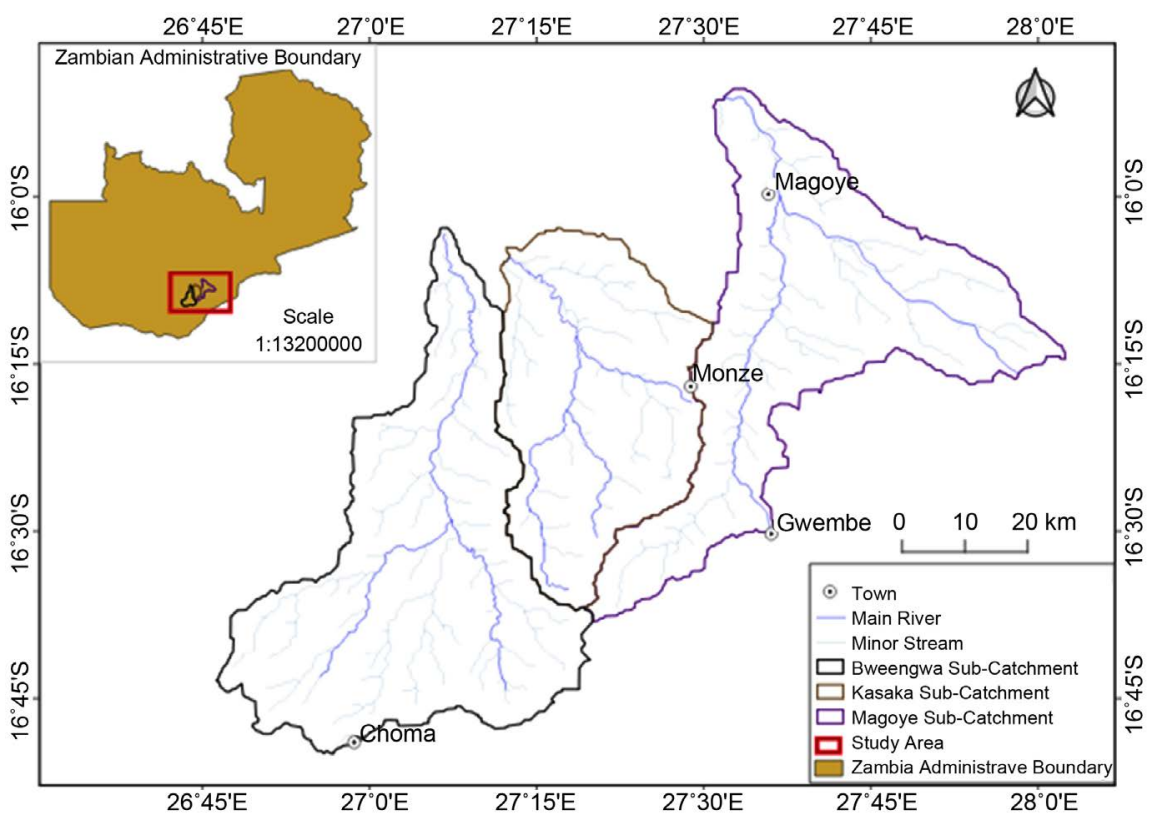

Figure 1. Location of the Mutama-Bweengwa, Kasaka and Magoye sub-catchments in Southern Zambia.

respective confluence is $99 \mathrm{~km}, 76 \mathrm{~km}$ and $167 \mathrm{~km}$ respectively. The 2018 estimated population were 115,316 for Mutama-Bweengwa, 89,869 for Kasaka and 117,462 for Magoye [19].

The elevation within the sub-catchments ranges from approximately $1225 \mathrm{~m}$ at the headwaters to $1000 \mathrm{~m}$ above sea level at the confluence with the Kafue River in the Kafue Flats [7]. The mean annual rainfall and temperature range between $650 \mathrm{~mm}$ to $800 \mathrm{~mm}$ and between $12^{\circ} \mathrm{C}-26^{\circ} \mathrm{C}$ respectively (WARMA, 2018). The three sub-catchments are located in Zambia's Agro-ecological Zone IIa [20] which is warm semi-arid conditions and annual climatic variation as indicated in the Compendium of Environmental Statistics [21].

In terms of livelihood, local communities inhabiting the three sub-catchments are largely subsistence farmers depending on rain-fed agriculture. However, the headwater streams of the sub-catchments support a number of commercial farmers. Land use activities such as industrial, brick-molding, sand mining, logging and charcoal production exist in the sub-catchments mainly at a small scale [22]. As shown in Figure 2, subsistence crop farm land is the dominant land use in the three sub-catchments and crop land cover has increased in the last decades, which contributed to loss of natural forests. The flat landscape parts of the sub-catchments are sparsely wooded grassland and prone to inundation due to increased runoff. The common types of vegetation in the sub-catchments include floodplain grassland, termitaria grasslands and woodlands.

\section{Data and Methods}

\subsection{WEAP Model Data Inputs}

The main types of inputs considered during the configuration of the WEAP 


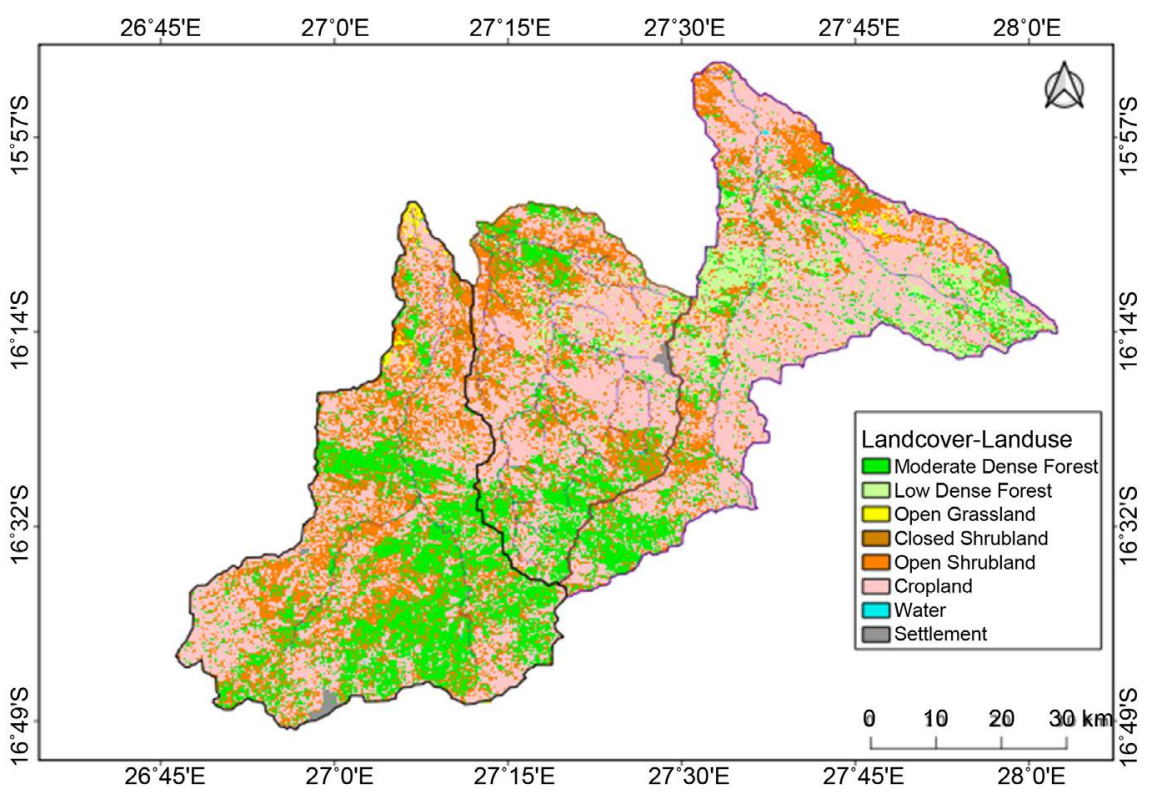

Figure 2. Land use land cover of the Mutama-Bweengwa, Kasaka and Magoye sub-catchments.

model were climate data and physical data. The climate data used were rainfall, temperature, relative humidity, wind speed and solar radiation. These data inputs where obtained from the Zambian Meteorological Department. Physical data inputs used were land use/land cover (Figure 2), soil information and catchment water uses. As sshown in Table 1 in which the priority orders 1 to 4 indicate that WEAP will first allocate all water demands to priority 1 node untilall water needs are met, then priority 2 water demand will follow in that order. Observed streamflow data were also used during hydrological calibration of the model. Catchment water use priorities are ranked based on the Zambian Water Management Act 2011 and Kafue Catchment water uses and allocation criteria proposed by the Water Resources Management Authority [23].

The theoretical aquifer storage capacity in Mutama-Bweengwa, Magoye and Kasaka sub-catchments were $11,176.69 \mathrm{Mm}^{3}, 3704.28 \mathrm{Mm}^{3}$ and $3357.19 \mathrm{Mm}^{3}$ respectively. These were estimated from WARMA's groundwater database and the BGR/GReSP Southern Province groundwater report [7] and were used respectively as input in the WEAP model. Two dams in every sub-catchment were selected to represent hydraulic structures. These were used to estimate storage capacity $Q\left[\mathrm{Mm}^{3}\right]$ using Equation (1) [24] were $L[\mathrm{~m}]$ is the length of the dam wall at the full supply level, $T[\mathrm{~m}]$ is the throwback (or fetch) of the reservoir measured in an approximately straight line from the wall, and $D[\mathrm{~m}]$ is the maximum water depth.

$$
Q=L \times T \times D / 6
$$

\subsection{WEAP Modelling}

\subsubsection{Model Configuration and Calibration}

Figure 3 shows the configuration and calibration of the WEAP model based on 
Table 1. Water use priorities in Mutama-Bweengwa, Kasaka and Magoye Sub-catchments.

\begin{tabular}{|c|c|c|c|c|}
\hline \multirow{2}{*}{$\begin{array}{l}\text { Water Use } \\
\text { Category }\end{array}$} & \multirow{2}{*}{$\begin{array}{c}\text { Water } \\
\text { Allocation } \\
\text { Model } \\
\text { Order of } \\
\text { Priority }\end{array}$} & \multicolumn{2}{|c|}{$\begin{array}{l}\text { Implemented in WEAP } \\
\text { with water source as }\end{array}$} & \multirow{2}{*}{ Comment } \\
\hline & & $\begin{array}{l}\text { Surface } \\
\text { Water }\end{array}$ & $\begin{array}{l}\text { Ground } \\
\text { Water }\end{array}$ & \\
\hline $\begin{array}{c}\text { Rural } \\
\text { domestic }\end{array}$ & 1 & Yes & Yes & $\begin{array}{l}\text { Implemented in both Historical and } \\
\text { Current Day setup of the Model }\end{array}$ \\
\hline $\begin{array}{c}\text { Urban } \\
\text { domestic }\end{array}$ & 1 & Yes & Yes & $\begin{array}{l}\text { Implemented in both Historical and } \\
\text { Current Day setup of the Model }\end{array}$ \\
\hline Livestock & 1 & Yes & Yes & $\begin{array}{l}\text { Implemented in both Historical and } \\
\text { Current Day setup of the Model }\end{array}$ \\
\hline Environment & 2 & No & No & $\begin{array}{l}\text { Implemented in current day setup } \\
\text { and according to Water Resources } \\
\text { Management Act of } 2011\end{array}$ \\
\hline $\begin{array}{l}\text { Bulk water } \\
\text { supply }\end{array}$ & 3 & No & No & $\begin{array}{l}\text { Not included in the model due to } \\
\text { Rural settlement dominance in the } \\
\text { sub-catchments }\end{array}$ \\
\hline Industrial & 4 & No & No & $\begin{array}{l}\text { Not included in the model due to } \\
\text { Rural settlement dominance in the } \\
\text { sub-catchments }\end{array}$ \\
\hline Agricultural & 4 & Yes & Yes & $\begin{array}{l}\text { Implemented in both Historical and } \\
\text { Current Day setup of the Model }\end{array}$ \\
\hline
\end{tabular}

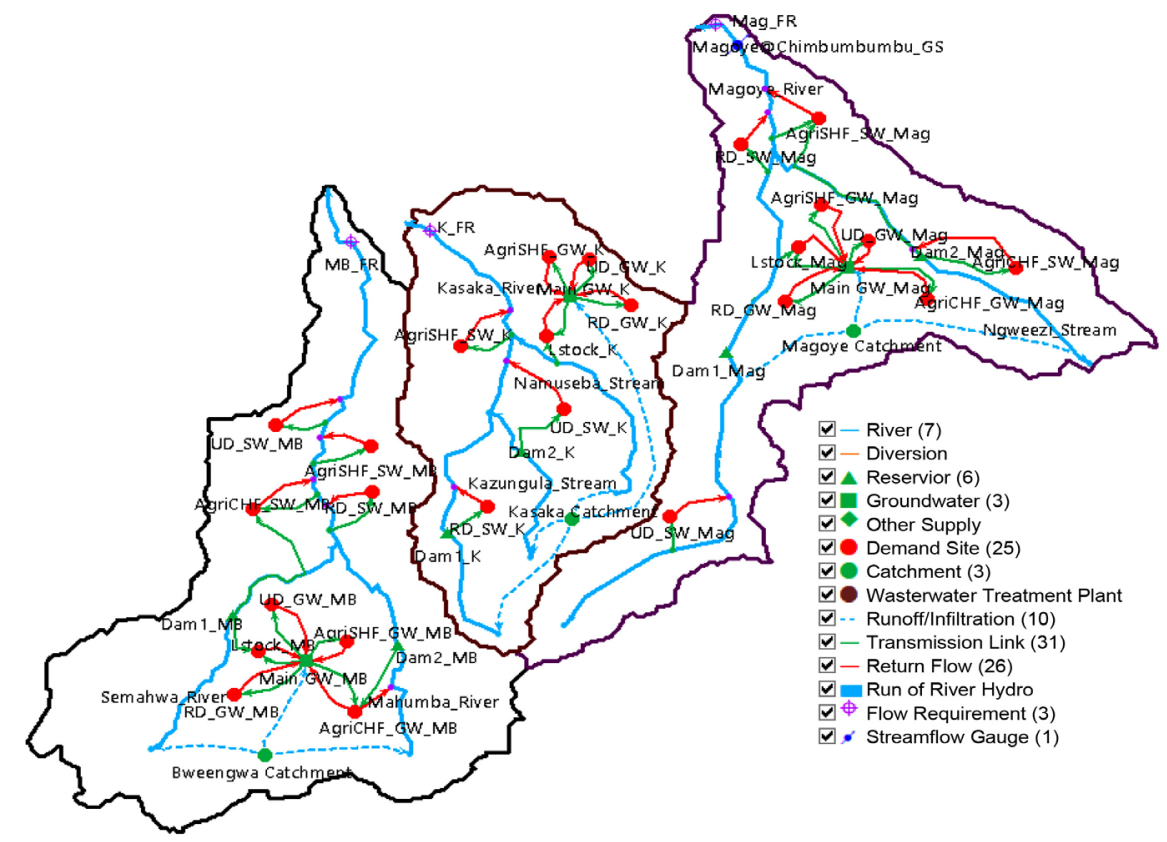

Figure 3. WEAP schematic map for the Mutama-Bweengwa, Kasaka and Magoye subcatchments.

a hydrological monthly time scale of 67 years (1951-2018) in historical mode to obtain a naturalized flow for the sub-catchments for use in the Current-Day configuration of the model.

Calibration and validation were conducted between 1971-1981 and 2008-2018 respectively using hydrological data for the three-river systems. Manual calibra- 
tion and validation were achieved under the historical mode of the model setup where observed discharge from the hydrometric station (Magoye River at Chimbumbumbu) and simulated discharge were statistically evaluated through the Nash-Sutcliffe Efficiency (NSE), and coefficient of determination $\left(\mathrm{R}^{2}\right)$ according to Equation (2) [25].

$$
\left\{\begin{array}{l}
\text { NSE }=1-\frac{\sum\left(Q_{o b s}-Q_{\text {sim }}\right)^{2}}{\sum\left(Q_{o b s}-\bar{Q}_{o b s}\right)^{2}} \\
\mathrm{R}^{2}=\frac{\left(\sum\left(Q_{o b s}-Q_{s i m}\right)\left(Q_{s i m}-\bar{Q}_{s i m}\right)\right)^{2}}{\sum\left(Q_{o b s}-\bar{Q}_{o b s}\right)^{2} \sum\left(Q_{s i m}-\bar{Q}_{s i m}\right)^{2}}
\end{array}\right.
$$

where $Q_{o b s}$ is observed discharge, $Q_{\text {sim }}$ is simulated discharge, $\bar{Q}_{o b s}$ is mean of the observed discharge, and $\bar{Q}_{\text {sim }}$ is the mean of the simulated discharge. The model performance was further evaluated using the PBIAS.

Table 2 shows the parameters used in the manual calibration of the WEAP model to simulate discharge data. The selected values were based on the location of the study area and the default values of the WEAP.

\subsubsection{Available Water in the Sub-Catchments}

The estimation of annual available water balance for selected years in the sub-catchments in Mutama-Bweengwa, Kasaka and Magoye was computed using the general water balance equation shown in Equation (3). All the main water balance components namely, Inflows, Outflows and Change in Storage $(\Delta S)$ were taken into account. Total water inflows into the sub-catchment must equal total water outflows from the sub-catchments [10].

$$
\mathrm{P}+\mathrm{ExtIn}=\mathrm{ET}+\text { Outflow }+\mathrm{ABST}+\Delta \mathrm{S}
$$

where $\mathrm{P}$ is precipitation, ExtIn is the amount of flow into the catchment besides precipitation, ET is evapotranspiration, Outflow is outflow from the catchment, ABST is the total abstraction for various uses and $\Delta S$ is the change in catchment storage.

Table 2. Calibration parameter ranges applied in WEAP model.

\begin{tabular}{ccc}
\hline Parameter & Model range & Optimal range \\
\hline $\begin{array}{c}\text { Soil water capacity } \\
\text { Roo zone } \\
\text { conductivity } \\
\text { Deep conductivity } \\
\begin{array}{c}\text { Runoff resistance } \\
\text { factor }\end{array}\end{array}$ & 0 - high $(\mathrm{mm})$ & $0-400 \mathrm{~mm}$ \\
$\begin{array}{c}\text { Crop coeficient } \\
\text { Preferred flow } \\
\text { direction }\end{array}$ & $0-1$ - higher $(\mathrm{mm} /$ month) Default $=20 \mathrm{~mm}$ & Default $=20 \mathrm{~mm}$ \\
\hline
\end{tabular}




\subsubsection{Unmet Water Demand under Different Future Scenarios}

Evaluation of all scenarios was achieved through WEAP using historical data from the year 1951 to 2018 and current day setup for the year 2020. Several scenarios were conducted on river restoration and assessment of the catchment water resource availability for allocation in the sub-catchments. The Current-Day setup in the WEAP Model provided the baseline against which scenarios were assessed. The Current Day Setup scenario was inherited from the reference scenario and comprised of water demand information for the year 2020. Table 3 shows the different scenarios considered in this study. Scenario modelling comprised of climate change both under 30\% reduction and increase in rainfall, environmental flow (e-flow) requirement implementation, improved agricultural practice together with e-flow and increase in commercial agriculture. Scenarios were then modelled in the same way as the 2018 demands. The new 2030 demand value was calculated by applying the population growth percentage, and then applied as a constant, unvarying demand over the full model period. This means no growing demand from 2018 to 2030 to get to future scenario demands, like in the historical 1951-2018 setup. Therefore, the demand values for 2018 and for the various scenarios in 2030 were kept constant, across the full 67-year model period. Among several scenarios conducted, e-flow implementation was one of the prominent due to the nature of the sub-catchment drainage characteristics which is flashy and non-perennial. Therefore, long-term mean monthly flows for Mutama-Bweengwa, Kasaka and Magoye were estimated on a 13-year record of observed streamflow data from the Magoye River at Chimbumbumbu hydrometric station and implemented as e-flow requirement in the WEAP model for e-flow implementation scenario. Climate change (30\% reduction/increase) and population growth rate at $3 \%$ scenarios were also considered in this study.

\section{Results and Discussion}

\subsection{Model Performance}

The performance of the model assessed for goodness-of-fit statistically achieved a Nash-Sutcliffe efficiency (NSE) of 0.83 (83\%) for calibration and $0.85(85 \%)$

Table 3. Other specific scenarios.

\begin{tabular}{cll}
\hline Scenario & \multicolumn{1}{c}{ Description } & Type of development in the sub-catchment \\
\hline 1a & $\begin{array}{l}\text { Improved livelihoods with } 30 \% \\
\text { imrovement in e-flows }\end{array}$ & $\begin{array}{l}\text { Increased demand, increased population, } \\
\text { increased irrigation, improved efficiency }\end{array}$ \\
2a & $\begin{array}{l}\text { Improved agricultural practices } \\
\text { with e-flow implementation }\end{array}$ & $\begin{array}{l}\text { No expansion in agriculture and improved } \\
\text { efficiency }\end{array}$ \\
3a & $\begin{array}{l}\text { Climate change with } 30 \% \\
\text { reduction in rainfall }\end{array}$ & $\begin{array}{l}\text { No increase in Population, No expansion in } \\
\text { agriculture, no efficiency }\end{array}$ \\
3b & $\begin{array}{l}\text { Climate change with } 30 \% \\
\text { increase in rainfall }\end{array}$ & $\begin{array}{l}\text { No increase in Population, No expansion in } \\
\text { agriculture, no efficiency }\end{array}$ \\
\hline
\end{tabular}


for validation and an $\mathrm{R}^{2}$ of 0.98 (98\%) for calibration and 0.95 (95\%) for validation [25]. The purpose for calibrating and validating the model before the scenario implementation is to achieve the naturalized streamflow to be used during water demand and allocation modelling. Based on the calibration and validation results, the performance of the WEAP hydrological model was considered satisfactory and therefore fit to achieve optimal analysis of water demand and allocation [26] in the Mutama-Bweengwa, Kasaka and Magoye sub-catchments and assess the water demand and allocation under different future scenarios [10]. Figure 4 gives a graphical comparison of the calibration and average validated streamflow for the period 1971-1981.

The average monthly flow validation for the year 2008-2018 is illustrated in Figure 5 where the overall peak streamflow in the sub-catchment is noticed during the month of January and February at $8.16 \mathrm{~m}^{3} / \mathrm{s}$ and $7.7 \mathrm{~m}^{3} / \mathrm{s}$ for the observed and simulated streamflow respectively.

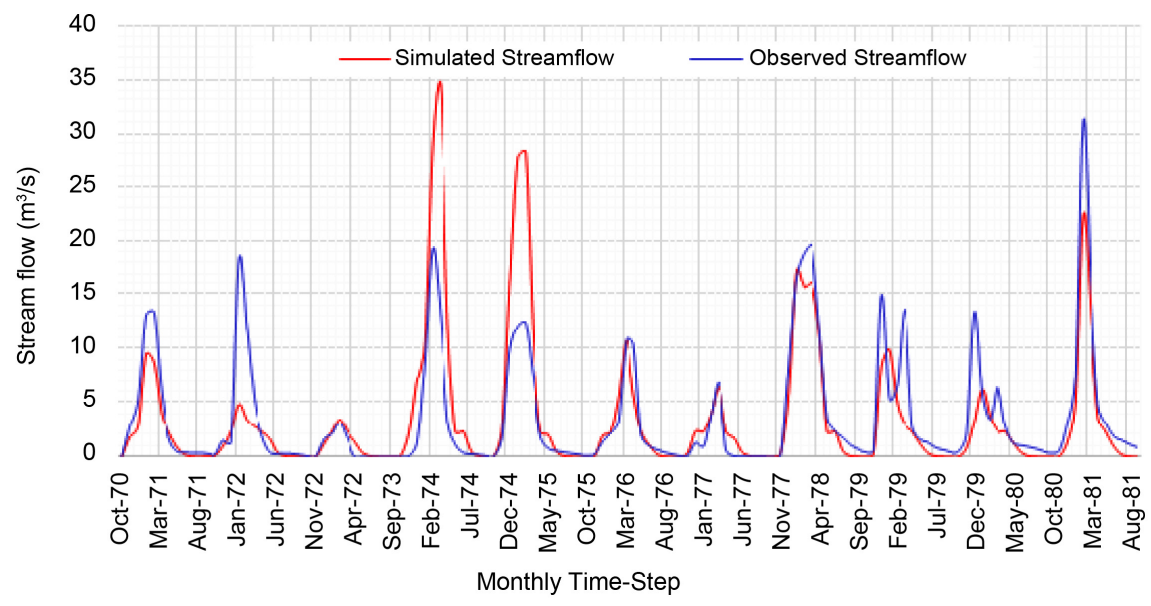

Figure 4. Model calibration: comparison of observed streamflow and simulated streamflow at Chimbumbumbu (4-915) on magoye river.

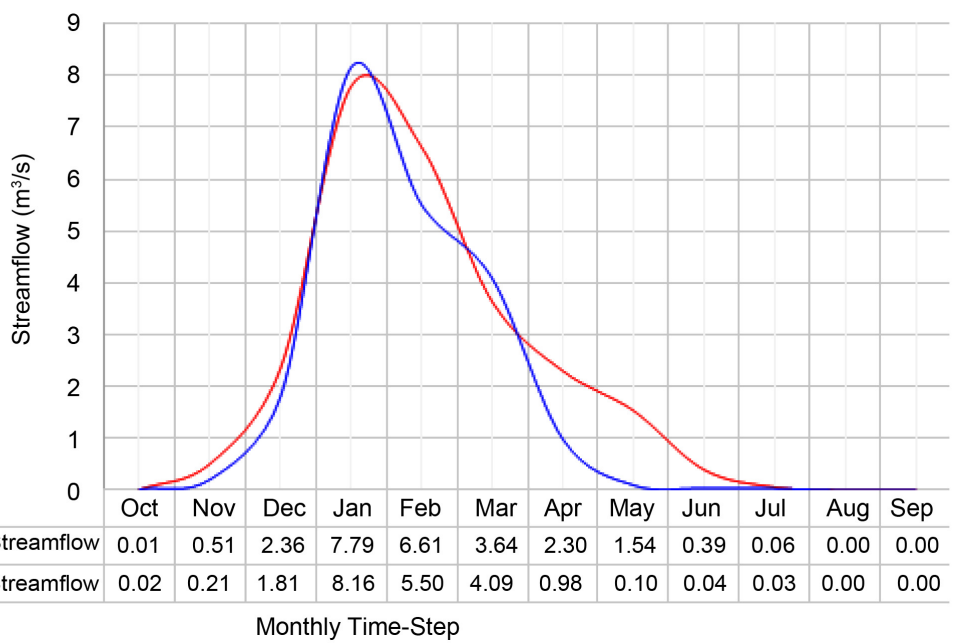

Figure 5. Model validation: comparison of observed and simulated mean monthly streamflow at Chimbumbumbu (4-915) on Magoye River. 


\subsection{Water Balance (Available Water) for Selected Years}

The water balances of the Mutama-Bweengwa, Kasaka and Magoye sub-catchments for selected years are as summarized in Table 4. The hydrological balance components were assessed and a hydrological model has been established for the respective sub-catchments. As shown in Table 4, the hydrological balance results for 2018 indicate Mutama-Bweengwa (210.948 $\mathrm{Mm}^{3} /$ year) Kasaka (1306.262 $\mathrm{Mm}^{3} /$ year) and Magoye (1777.546 $\mathrm{Mm}^{3} /$ year) of water received from precipitation. It was estimated that about $90.2 \%$ (1815.259 $\mathrm{Mm}^{3} /$ year) from Mutama-Bweengwa, 89\% (1162.655 $\mathrm{Mm}^{3} /$ year) from Kasaka and 84.7\% (1505.664 $\mathrm{Mm}^{3}$ /year) from Magoye sub-catchments were evaporated. The estimated abstraction rate increases over time and about $746.599 \mathrm{Mm}^{3}$ for Mutama-Bweengwa, 314.350 $\mathrm{Mm}^{3}$ for Kasaka and 706.954 $\mathrm{Mm}^{3}$ from Magoye abstracted from the respective catchments in 2018. The water was abstracted for various purposes such as irrigation, domestic/industrial, rural water supply and livestock uses. The overall storage water of the respective sub-catchments in the year 2018 indicated a substantial reduction as shown in Table 5. Generally, the water balance estimates indicated that there is a negative water balance in the sub-catchments for the year 2018 .

Table 4. Water balance for selected years in Mutama-Bweengwa, Kasaka and Magoye Sub-catchments.

\begin{tabular}{|c|c|c|c|c|c|}
\hline Year & $\begin{array}{l}\text { Precipitation } \\
\left(\mathrm{Mm}^{3}\right)\end{array}$ & $\begin{array}{l}\text { Streamflow } \\
\left(\mathrm{Mm}^{3}\right)\end{array}$ & $\begin{array}{c}\text { Evapotranspiration } \\
\left(\mathrm{Mm}^{3}\right)\end{array}$ & $\begin{array}{l}\text { Abstraction } \\
\left(\mathrm{Mm}^{3}\right)\end{array}$ & $\begin{array}{l}\text { Storage } \\
\left(\mathrm{Mm}^{3}\right)\end{array}$ \\
\hline \multicolumn{6}{|c|}{ Mutama-Bweengwa Sub-catchment } \\
\hline 1990 & 1775.546 & 10.969 & 1648.915 & 214.330 & 23.501 \\
\hline 1997 & 2261.618 & 59.545 & 1947.917 & 250.377 & 146.494 \\
\hline 2004 & 1852.210 & 10.048 & 1988.006 & 286.997 & 30.748 \\
\hline 2011 & 2025.541 & 13.277 & 1833.268 & 509.014 & -39.880 \\
\hline 2018 & 2010.948 & 38.947 & 1815.259 & 746.599 & -164.295 \\
\hline \multicolumn{6}{|c|}{ Kasaka Sub-catchment } \\
\hline 1990 & 1153.350 & 51.778 & 1036.226 & 187.306 & 9.153 \\
\hline 1997 & 1469.091 & 100.801 & 1273.267 & 216.717 & 30.008 \\
\hline 2004 & 1203.149 & 43.892 & 1086.670 & 246.629 & -1.402 \\
\hline 2011 & 1315.741 & 60.616 & 1176.260 & 277.438 & -4.366 \\
\hline 2018 & 1306.262 & 68.323 & 1162.655 & 314.350 & -19.021 \\
\hline \multicolumn{6}{|c|}{ Magoye Sub-catchment } \\
\hline 1990 & 1569.466 & 56.555 & 1370.452 & 372.843 & 0.778 \\
\hline 1997 & 1999.122 & 134.086 & 1606.825 & 435.755 & 92.623 \\
\hline 2004 & 1637.232 & 57.988 & 1405.243 & 499.583 & -15.840 \\
\hline 2011 & 1790.445 & 79.776 & 1520.601 & 598.216 & -37.254 \\
\hline 2018 & 1711.546 & 89.608 & 1505.664 & 706.954 & -86.368 \\
\hline
\end{tabular}


Table 5. Unmet water demand in $\mathrm{Mm}^{3}$ per demand site in the sub-catchments under the four scenarios.

\begin{tabular}{|c|c|c|c|c|}
\hline \multirow[b]{2}{*}{ Demand Site } & \multicolumn{4}{|c|}{ Unmet Water Demand in $\mathrm{Mm}^{3}$ for Selected Scenarios } \\
\hline & $\begin{array}{l}\text { Current day } \\
\text { Scenario }\end{array}$ & Scenario $2 a$ & Scenario $3 a$ & Scenario $3 b$ \\
\hline \multicolumn{5}{|c|}{ Mutama-Bweengwa (MB) Sub-catchment } \\
\hline AgriCHF_GW_MB & 12.040 & 9.134 & 10.518 & 13.937 \\
\hline AgriCHF_SW_MB & 14.700 & 11.141 & 12.840 & 17.018 \\
\hline AgriSHF_GW_MB & 7.990 & 6.416 & 7.990 & 7.990 \\
\hline AgriSHF_SW_MB & 14.981 & 11.354 & 13.086 & 17.343 \\
\hline RD_GW_MB & 0.739 & 0.739 & 0.723 & 0.763 \\
\hline RD_SW_MB & 1.282 & 1.281 & 1.255 & 1.319 \\
\hline Sub Total & 50.450 & & & \\
\hline \multicolumn{5}{|c|}{ Kasaka (K) Sub-catchment } \\
\hline AgriSHF_GW_K & 7.376 & 5.575 & 7.360 & 7.407 \\
\hline AgriSHF_SW_K & 8.983 & 6.838 & 7.869 & 10.912 \\
\hline \multicolumn{5}{|l|}{ Sub Total } \\
\hline \multicolumn{5}{|c|}{ Magoye (Mag) Sub-catchment } \\
\hline AgriCHF_GW_Mag & 3.707 & 2.976 & 3.707 & 3.707 \\
\hline AgriCHF_SW_Mag & 2.623 & 1.982 & 2.222 & 3.214 \\
\hline AgriSHF_GW_Mag & 13.980 & 11.225 & 13.980 & 13.980 \\
\hline AgriSHF_SW_Mag & 23.084 & 17.445 & 19.551 & 28.283 \\
\hline \multicolumn{5}{|l|}{ Sub Total } \\
\hline $\begin{array}{l}\text { All Other Demand } \\
\text { Sites }\end{array}$ & 2.300 & 2.296 & 1.915 & 2.917 \\
\hline Grand Total & 113.784 & 88.402 & 103.015 & 128.790 \\
\hline
\end{tabular}

AgricCHF $=$ Commercial Farming, AgricSHF $=$ Small scale Farming, GW = Ground Water, SW = Surface Water, $\mathrm{MB}=$ Mutama-Bweengwa, $\mathrm{K}=$ Kasaka, Mag = Magoye, $\mathrm{RD}=$ Rural Domestic.

\subsection{Unmet Water Demand under Different Scenarios}

Figure 6 shows that the unmet water demand in the sub-catchments is highest in the months of September-October and lowest in February regardless of the scenario considered in this study. The water demand ranges are $110 \mathrm{Mm}^{3}$ to 205 $\mathrm{Mm}^{3}$ under the increase in commercial agriculture scenario, $40 \mathrm{Mm}^{3}$ to $115 \mathrm{Mm}^{3}$ under the improved agriculture \& e-flow implementation scenario, $40 \mathrm{Mm}^{3}$ to $140 \mathrm{Mm}^{3}$ under the $30 \%$ increase in rainfall scenario, $100 \mathrm{Mm}^{3}$ to $140 \mathrm{Mm}^{3}$ under the $30 \%$ reduction in rainfall scenario, and about $60 \mathrm{Mm}^{3}$ to $140 \mathrm{Mm}^{3}$ under the Current Day Setup (2020).

Climate variability, e-flow requirement, improved agricultural practice with e-flow implementation and increased commercial agriculture scenarios were applied across the sub-catchments. The climate variability with $30 \%$ increase in 


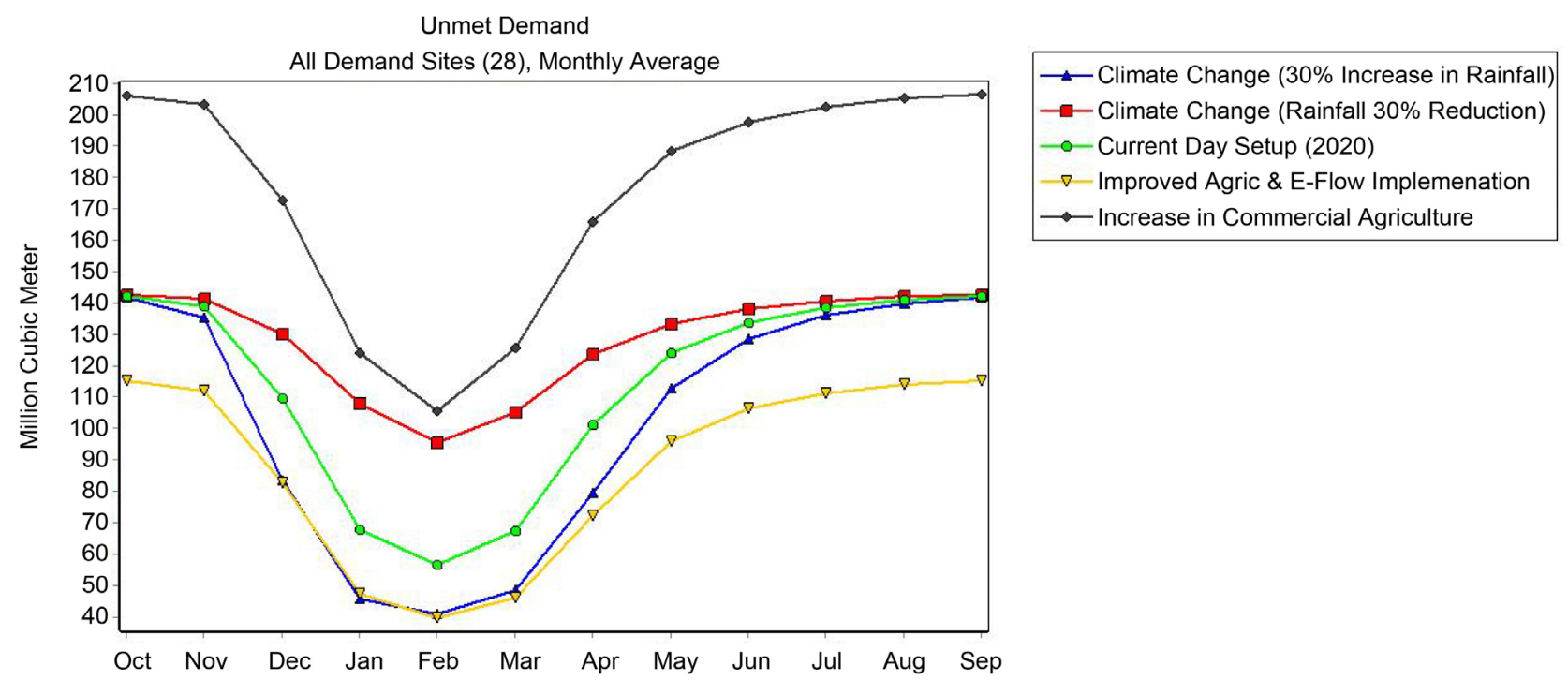

Figure 6. Unmet water demand under the different scenarios.

rainfall showed improvement in stream flow leading to reduction in unmet demands from $140 \mathrm{Mm}^{3}$ to $40 \mathrm{Mm}^{3}$ in the month of October and February, respectively while current-day demand setup had the reductions from $140 \mathrm{Mm}^{3}$ in the month of October to $50 \mathrm{Mm}^{3}$ during the month of February there by representing $10 \%$ reduction in unmet water demand for this scenario.

Table 5 gives scenario comparison between current-day and improved agriculture with e-flow requirement implementation showing a reduction in the unmet demand in the sub-catchments. The reduction in unmet demand from $113 \mathrm{Mm}^{3}$ to $88 \mathrm{Mm}^{3}$ for the Scenario 2a (Current-day Scenario) implies $78 \%$ of the assured met water demand in the sub-catchments. Improved agricultural practice with e-flow and 30\% increase in rainfall scenarios showed a significant reduction in unmet water demands in the Sub-catchment between Scenarios 2a and 3a. The reduction in unmet water demand from $140 \mathrm{Mm}^{3}$ (under scenario 3a.) to $115 \mathrm{Mm}^{3}$ (under scenario 2a.) was observed in the month of October while the minimum unmet water demand of $40 \mathrm{Mm}^{3}$ for both scenarios was indicated in the month of February (Figure 6).

The increased commercial agricultural scenario showed an increase in unmet water demand increase from $140 \mathrm{Mm}^{3}$ to $207 \mathrm{Mm}^{3}$ particularly in the month of October representing a $67 \%$ rise. This is likely to further stress the water system in the sub-catchments. The minimum unmet water demand under increase commercial agriculture was noticed during the month of February as $115 \mathrm{Mm}^{3}$.

The scenario assessment shows, different way to river restoration and allocation of available water to the competing users in the sub-catchments. Changing cropping patterns (scenario 2a) while maintaining the size of the agricultural area shows reduction of stress on water resources and hence improving the availability of the resources to the users as compared to the results obtained under current day demands. Comparing to the current day (reference/baseline scenario), implementation of scenario $2 \mathrm{a}$ and $3 \mathrm{a}$ showed achievable results towards 


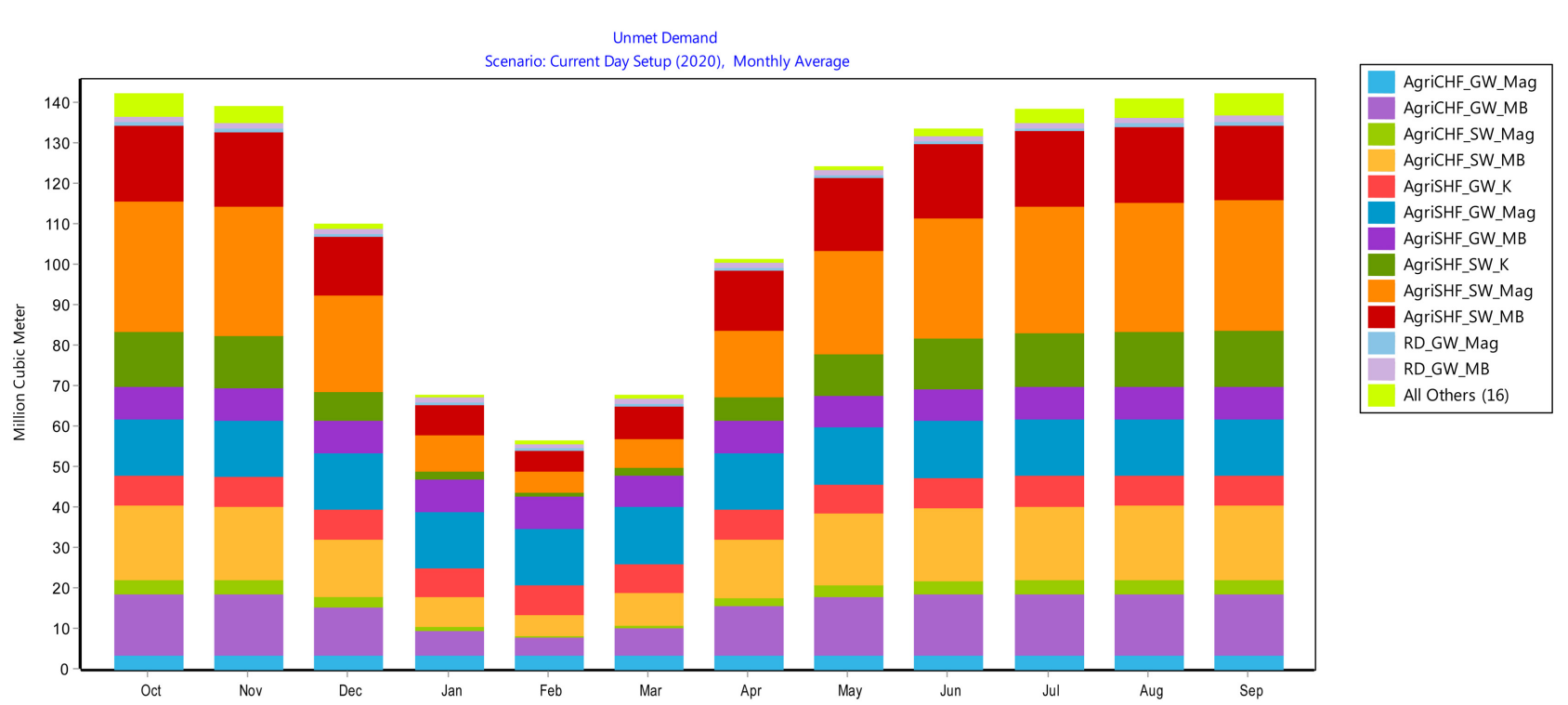

Figure 7. Monthly average of site unmet water demand.

river restoration and improved water availability in the sub-catchments while scenario $3 \mathrm{~b}$ and the increased commercial agriculture scenario impacted negatively in the sub-catchments through the noticeable increased unmet demands.

Table 5 shows water demand under the four scenarios per demand site. The values in the table suggest that commercial agriculture is the largest water user in both Mutama-Bweengwa and Magoye sub-catchments while rural domestic water and livestock uses had the lowest water demands. In terms of unmet water demand, scenario 2a (Improved Agriculture with e-flow implementation) has the least amount of $88.402 \mathrm{Mm}^{3}$ followed by Scenario 3a (Climate Change 30\% increase in Rainfall) with $103.015 \mathrm{Mm}^{3}$, Current Day (2020) Scenario with $113.784 \mathrm{Mm}^{3}$ and finally scenario 3b (Climate Change 30\% Rainfall Reduction) with the largest amount of $128.790 \mathrm{Mm}^{3}$.

The variation in monthly water demand at the 13 demand sites given in Table 5 is further illustrated in Figure 7.

\section{Conclusions and Recommendations}

\subsection{Conclusions}

The study has determined the available water resources in the Mutama-Bweengwa, Kasaka and Magoye sub-catchments and the water demand under different future scenarios using historical hydrological data in the WEAP model. It has revealed that there is an increase in the water demands for various purposes, with commercial agriculture becoming the largest water consumer in the sub-catchments.

1) The three sub-catchments are clearly experiencing an increase in water deficit. If not addressed, the water scarcity may trigger conflicts over future water allocations amongst the various water users and could retard the desired socio-economic in the sub-catchments.

2) The total unmet water demand for all types of uses in the sub-catchments 
under the Current-Day/Baseline scenario is $113 \mathrm{Mm}^{3}$.

3) The total unmet demand for future scenarios in the sub-catchments for all types of uses is $88 \mathrm{Mm}^{3}$ under improved agriculture and e-flow implementation, $103 \mathrm{Mm}^{3}$ under $30 \%$ increase in rainfall and $128 \mathrm{Mm}^{3}$ under $30 \%$ reduction in rainfall.

4) In all scenario evaluations, the maximum unmet water demands were felt during the month of October while the month of February had the minimum unmet water demand.

5) Improved agricultural practices (while maintaining the size of cropland) with e-flow requirement implementation comparatively reduced the water demand in the sub-catchments thereby improving the coverage and unmet water demands.

6) Meeting the water demand of the ever-growing population and associated socio-economic development activities in the sub-catchments is possible. However, this requires appropriate water resources management and monitoring interventions.

\subsection{Recommendations}

Based on the findings and conclusions of this study, the following recommendations have been proposed:

1) Implementation of improved agriculture practices and e-flow (scenario 2a) to restore the Magoye River system, improve the catchment water availability and reduce the unmet water demands in the sub-catchments.

2) Implement water harvesting techniques such as small reservoir construction, ponds, check dams and afforestation activities to capture peak river runoff for usage in the dry period (The hydrological flow pattern in the sub-catchments is flashy).

3) Implementation of integrated catchment strategies through formation of water user associations [10].

4) Groundwater exploration through the construction of communal kiosks to improve reduction in the unmet catchment water demands.

5) Development and implementation of a water user monitoring and information platform similar to Kaleya Catchment portal [27].

6) Establishment of hydrometric stations in the respective sub-catchments to improve water resources monitoring and water availability estimations for various user allocation.

\section{Conflicts of Interest}

The authors declare no conflicts of interest regarding the publication of this paper.

\section{References}

[1] Ngo, L.A., Ilyas, M., Yong, J. and Wim, D. (2016) Impact of Reservoir Operation and Climate Change on the Hydrological Regime of the Sesan and Srepok Rivers in 
the Lower Mekong Basin. Climatic Change, 149, 107-119.

https://doi.org/10.1007/s10584-016-1875-y

[2] Tidwell, V.C., Moreland, B.D., Shaneyfelt, C.R. and Kobos, P. (2018) Mapping Water Availability, Cost and Projected Consumptive Use in the Eastern United States with Comparisons to the West. Environmental Research Letters, 13, Article ID: 014023. https://doi.org/10.1088/1748-9326/aa9907

[3] Kumar, N., Singh, S.K., Singh, V.G. and Dzwairo, B. (2018) Investigation of Impacts of Land Use/Land Cover Change on Water Availability of Tons River Basin, Madhya Pradesh, India. Modelling Earth Systems and Environment, 4, 1-16. https://doi.org/10.1007/s40808-018-0425-1

[4] Tidwell, V.C., et al. (2014) Mapping Water Availability, Projected Use and Cost in the Western United States. Environmental Research Letters, 9, Article ID: 064009. https://doi.org/10.1088/1748-9326/9/6/064009

[5] Barlow, P.M., Alley, W.M. and Myers, D.N. (2004) Hydrological Aspects of Water Sustainability and Their Relation to a National Assessment of Water Availability and Use. Water Resources Update, No. 127, 76-86.

[6] Saraiva, A.M.L., et al. (2015) Drivers of Spatial and Temporal Variability of Streamflow in the Incomati River Basin. Hydrology and Earth Sciences, 19, 657-673. https://doi.org/10.5194/hess-19-657-2015

[7] Bäumle, R., Neukum, C., Nkhoma, J. and Silembo, O. (2007) The Groundwater of Southern Province, Zambia (Phase 1). Federal Institute for Geosciences and Natural Resources (BGR), Lusaka.

[8] Stockholm Environment Institute (SEI) (2015) WEAP21: Water Evaluation and Planning System-Tutorial and User Guide. Stockholm Environment Institute, Boston.

[9] Yates, D., Sieber, J., Purkey, D. and Huber-Lee, A. (2005) WEAP21 a Demand, Priority and Preference Driven Water Planning Model, Part 1: Model Characteristics. Water International, 30, 487-500. https://doi.org/10.1080/02508060508691893

[10] Tena, T.M., Phenny, M. and Nguvulu, A. (2019) Hydrological Modelling and Water Resources Assessment of Chongwe River Catchment Using WEAP Model. Water, 11, 839. https://doi.org/10.3390/w11040839

[11] Ayt Ougougdal, H., Yacoubi Khebiza, M., Messouli, M. and Lachir, A. (2020) Assessment of Future Water Demand and Supply under IPCC Climate Change and Socio-Economic Scenarios, Using a Combination of Models in Ourika Watershed High Atlas, Morocco. Water, 12, 1751. https://doi.org/10.3390/w12061751

[12] Tena, T.M., Phenny, M. and Nguvulu, A. (2019) Impact of Land Use/Land Cover Change on Hydrological Components in Chongwe River Catchment. Sustainability, 11, 6415. https://doi.org/10.3390/su11226415

[13] Vogel, R.M., Sieber, J., Archfield, S.A., Smith, M.P., Apse, C.D. and Huber-Lee, A. (2007) Relations among Storage, Yield, and Instream Flow. Water Resources Research, 43, W05403. https://doi.org/10.1029/2006WR005226

[14] Arranz, R. and McCartney, M.P. (2007) Application of the Water Evaluation and Planning (WEAP) Model to Assess Future Water Demands and Resources in the Olifants Catchment. IWMI Working Paper 116, IWMI-International Water Management Institute, Pretoria, 91.

[15] McCartney, M., Ibrahim, Y.A., Sileshi, Y. and Awulachew, S.B. (2009) Application of the Water Evaluation and Planning (WEAP) Model to Simulate Current and Future Water Demand in the Blue Nile. Proceedings in Intermediate Results Dissemination Workshop on Improved Water and Land Management in the Ethiopian 
Highlands: Its Impact on Downstream Stakeholders Dependent on the Blue Nile, Addis Ababa, 5-6 February 2009, 78-88.

[16] Mounir, Z.M., Chuan, M.M. and Issoufou, A. (2011) Application of Water Evaluation and Planning (WEAP): A Model to Assess Future Water Demands in the Niger River (In Niger Republic). Journal of Modern Applied Science, 5, 38-49.

https://doi.org/10.5539/mas.v5n1p38

[17] Gedefaw, M., Wang, H., Yan, D., Qin, T., Wang, K., Girma, A., Batsuren, D. and Abiyu, A. (2019) Water Resources Allocation Systems under Irrigation Expansion and Climate Change Scenario in Awash River Basin of Ethiopia. Water, 11, 1966. https://doi.org/10.3390/w11101966

[18] Rukuni, S. (2006) Modeling the Response of Small Multi-Purpose Reservoirs to Hydrology for Improved Rural Livelihoods in the Mzingwane Catchment: Limpopo Basin. M.Sc. Thesis, University of Zimbabwe, Harare.

[19] CSO (2014) 2010 Census of Population and Housing. Lusaka Province Analytical Report, Central Statistics Office (CSO), Lusaka.

[20] ZMD (2019) Ministry of Transport and Communications (Zambia Meteorological Department). https://www.mtc.gov.zm/?page_id=5528

[21] CSO (2018) Compedium of Environment Statistics, 2015. Central Statistical Office, Lusaka.

[22] ZDA (2011) Agriculture, Livestock and Fisheries Sector Profile. Zambia Development Agency, Lusaka.

[23] WARMA (2019) Kafue Catchment Plan. Prepared by WARMA and GIZ.

[24] Stephens, T. (1991) Manual on Small Earth Dams. FAO, Rome.

[25] Moriasi, D.N., et al. (2007) Model Evaluation Guidelines for Systematic Quantification of Accuracy in Watershed Simulations. Transactions of the ASABE, 50, 885-900. https://doi.org/10.13031/2013.23153

[26] Alfarra, A., et al. (2012) Modeling Water Supply and Demand for Effective Water Management Allocation in the Jordan Valley. Journal of Agricultural Science and Applications (JASA), 1, 1-7. https://doi.org/10.14511/jasa.2012.010101

[27] WARMA (2018) Kaleya Portal. http://www.kaleyaportal.warma.org.zm 